\title{
Small Cell Adenocarcinoma
}

National Cancer Institute

\section{Source}

National Cancer Institute. Small Cell Adenocarcinoma. NCI Thesaurus. Code C129449.

An adenocarcinoma composed of small malignant cells. 